\title{
Traditional Methods for Whey Protein Isolation and Concentration: Effects on Nutritional Properties and Biological Activity
}

\author{
Xóchitl Tovar Jiménez, Ainhoa Arana Cuenca, Alejandro Téllez Jurado, Arturo Abreu Corona, and \\ Claudia Rosario Muro Urista*
}

\begin{abstract}
Departamento de Investigación de Ingeniería Química, Instituto Tecnológico de Toluca. Av. Tecnológico s/n Ex-Rancho la Virgen, C.P. 52140. Toluca, México. cmuro@ittoluca.edu.mx
\end{abstract}

Received March 7, 2012; Accepted May 28, 2012

\begin{abstract}
Traditional methods used for concentration of whey proteins have various levels of performance and effects on the nutritional properties and biological activities of the products. In this study, we showed that the greatest protein content was obtained using ultrafiltration and salt treatment methods. The effective concentration was approximately $40-53 \%(\mathrm{w} / \mathrm{w})$ protein. Using electrophoresis and solubility tests, we also found that these methods offer the fundamental advantage of maintaining certain proteins in their native states. The products maintained key ABTS $\bullet+$ radical scavenging activity; however, the antimicrobial activity was adversely affected by these separation methods.
\end{abstract}

Key words: Activity, Whey, Protein Concentration, Antioxidant, Antimicrobial.

\section{Introduction}

Whey contains various bioactive components that demonstrate a range of immune-enhancing properties [1]. Several studies have shown that whey-derived components can reduce the risk of metabolic syndrome, which can lead to various chronic diseases, such as cardiovascular disease and diabetes [2]. Clinical trials aimed at using whey in the treatment of cancers affecting the immune system have been successful [3]. Health problems associated with HIV, hepatitis B and osteoporosis have also been reduced, either directly or indirectly, by the use of whey components [4-6]. Thus, whey provides health benefits to humans of all ages by providing specific bioactive components (above and beyond those necessary for nutrition) [7]. Whey's biological activities are partially attributable to specific peptides encoded in proteins. The activities of such peptides, which can be manifold, are manifested upon proteolytic digestion, which releases bioactive peptides from the original protein [89]. Whey contains high levels of branched-chain amino acids (BCAAs), i.e., leucine, isoleucine and valine. Leucine is an important factor for tissue growth and repair and has been identified as a key amino acid for the initiation of translation. Whey proteins are also rich in the sulphur-containing amino acids cysteine and methionine. These amino acids enhance immune function upon intracellular conversion to glutathione, a potent antioxidant [10].

Currently scientific and commercial interest is focused on the biological properties and nutritional value of whey proteins. Products such as infant and hypoallergenic foods and sports drinks have prompted the selection and development of
Resumen. Los métodos tradicionales para la concentración de proteínas de suero lácteo afectan el rendimiento del proceso, las propiedades nutricionales de los productos y su actividad biológica. En este estudio se muestra que el más alto contenido de proteína verdadera $40-53 \%$ (w/w) se encuentra en los productos obtenidos de la ultrafiltración y precipitación por adición de sales. Los resultados de electroforesis y solubilidad de las proteínas revelaron que estos métodos ofrecen la ventaja fundamental de mantener las proteínas en su estado nativo. Los productos mostraron una importante actividad antioxidante pero la actividad antimicrobiana se vio afectada por los métodos de separación.

Palabras clave: Lactosuero, concentración de proteínas, actividad antioxidante, actividad antimicrobiana.

methods for isolating and concentrating individual whey proteins or a set protein in a purified or enriched form, i.e., whey protein concentrates (WPC) or protein isolates (WPI). These methods variously rely on denaturation (salt treatment processes, heat and $\mathrm{pH}$ treatments), ionic selection (electrophoresis, ion-exchange chromatography), selection according to shape and size (membrane filtration, gel permeation and size-exclusion chromatography), polarity (high-performance liquid chromatographic), chemical reactivity (complexation) and physical properties (coacervation, foaming and freeze-drying). Some of these processes have not been widely implemented for largescale separation because of their complexity, high cost, low overall yield, poor selectivity, low product activity, or product degradation associated with the extremes of heat, $\mathrm{pH}$ and salt used during the process [11]. Membrane separation processes, such as ultrafiltration (UF), reverse osmosis (RO) and diafiltration (DF), in particular, are now industrially applied in the manufacture of ordinary whey powder and WPCs with protein contents of $30-80 \%$. Gel filtration and ion-exchange chromatography techniques are also employed in the manufacture of WPIs with protein contents of 90-95\% [12], but the whey protein content of these isolates is not always up to this level [13].

Precipitation methods are often used at the laboratory scale to obtain whey protein concentrates and produce peptides; however, the chemical composition and functionality of whey protein preparations and peptides are affected by the method used in the proteins concentration process. Chemical additives and factors, such as pressure, temperature, agitation rate and holding time, have been shown to affect solvent $\mathrm{pH}$, protein 
conformation and yield $[13,14]$. In particular, protein purity is critical for the biological activity of concentrated products. In addition, the biological properties of the concentrated products are difficult to standardise due to the complex nature of the bioactivities exerted by different whey proteins [15-17].

The objective of this study was to assess laboratory methods for whey protein concentration. The nutritional composition and biological activities of products derived from all methods were compared. Our research has important implications for the production of active peptides derivatives of various whey protein concentrates.

\section{Results and discussion}

\section{Whey composition}

The whey samples had a yellowish colour, a fresh taste and a $\mathrm{pH}$ of 5 to 6.6. The average composition of basic nutrients in $\mathrm{g} / \mathrm{L}$ (proteins $12.13 \pm 0.1$, total sugars $48.43 \pm 0.3$, calcium 0.64 \pm 0.2 , fat $3.9 \pm 0.2$, ash $15.12 \pm 0.01$ and chloride $1.02 \pm 0.3$ ) was characteristic of sweet whey.

The sugar content and $\mathrm{pH}$ indicated that this whey was probably obtained by producing sweet cheese with rennin at $\mathrm{pH}$ 6.5. The results reported by Pereira [27], Díaz [28] and Panesar [29] show that the lactose contents of acid whey and sweet whey are 44-46 to $46-52 \mathrm{~g} / \mathrm{L}$, respectively, while the $\mathrm{pH}$ is between 4.2 and 6.6. No striking difference in protein content between sweet and acid whey (6-13 g/L) has been reported; this value depends on the technological process used to manufacture the cheese and the milk used as a base [30]. However, sugar and protein contents are also indicators of whey quality; both are relevant factors in the manufacture of nutraceutical products and foods with biological activities [31]. For example, caseinoglycopeptide (CGP, an active component of sweet whey naturally produced during the processing of ripened cheese) contains sugar moieties and phosphorus and helps give whey a high nutritional value and multifunctional properties. CGP has effects on opioid receptors, calcium absorption, immunoactivating, angiotensin-converting enzyme (ACE) and bifidus factors. This protein also inhibits the adhesion of Streptococcus and Actinomyces viscosus and binds to cholera toxin, Salmonella enteritidis and E. coli $\mathrm{O} 157: \mathrm{H} 7$. In the case of Salmonella,
Nakajima [32] found that CGP is a promising agent for preventing intestinal infection.

Another beneficial effect of high lactose content in whey, namely an increase in the intestinal absorption of calcium, was reported by Guéguen and Pointillart [33]. Binding of calcium by $\alpha$-La and $\beta$-Lg has also been clearly demonstrated in both in vitro studies and in short- and long-term trials in rats. Thus, it is clear that whey contains significant nutritive elements and bioactive substances [34].

\section{Characteristics of whey protein products (WPC)}

\section{Nutritional properties}

Four products were obtained from whey protein concentrates (WPC). The average nutritional composition from each product is shown in Table 1. The $\mathrm{pH}$ of the samples was between 6 and 7.

The whey concentration method used had a significant effect on protein recovery. The ultrafiltration method had the best gravimetric yield of dry base and recovery of proteins from whey. The protein yield was calculated as $40-53 \%$, which represents an increase of approximately $10 \%$ compared with thermal precipitation and hydrochloric acid preparation methods. The contents of sugars, fat, ash and other solids yielded no purified whey products. In addition, the high NPNC values obtained indicate an NT content of $10-15 \%$ in the whey products obtained by precipitation methods.

A similar composition was reported by Modler [35], Pereira [27] and Díaz [28], who evaluated cheese whey and deproteinised whey (Sorelho) protein concentrates. Both of these by products of cheese manufacture were clarified by thermocalcic precipitation and microfiltration using membranes of two different pore sizes (0.65 and 0.20 $\mu \mathrm{m})$.

The levels of ash and sugar obtained using the acetone and ammonium sulphate precipitation methods were similar to values reported by Foegeding and Luck [16], who found that the amount of ash obtained with these methods was increased due to the use of solvents and salts. In addition, the use of ammonium sulphate limits bacterial growth and protects proteins from denaturation, enabling recovery of non-denatured globulins. The disadvantage of this method is the need for dialysis or ultrafiltration to remove salt.

Table 1. Chemical composition (g/100 g powder) of whey protein products.

\begin{tabular}{lccccc}
\hline \multicolumn{1}{c}{$\begin{array}{c}\text { Concentration whey } \\
\text { proteins Method }\end{array}$} & Protein & NPNC & Total sugars & Fat & Ash \\
\hline Salt treatment & $31.19 \pm 0.6$ & 3.40 & $5.67 \pm 0.3$ & $3.3 \pm 0.1$ & $15.4 \pm 0.01$ \\
Acetone precipitation & $29.32 \pm 0.4$ & 4.56 & $4.27 \pm 0.3$ & $5.9 \pm 0.2$ & $14.6 \pm 0.03$ \\
$\begin{array}{l}\text { Hydrochloric acid } \\
\text { precipitation }\end{array}$ & $27.28 \pm 0.5$ & 5.50 & $5.03 \pm 0.4$ & $4.7 \pm 0.1$ & $10.0 \pm 0.01$ \\
Thermal precipitation & $29.43 \pm 0.3$ & 5.65 & $5.46 \pm 0.2$ & $2.5 \pm 0.2$ & $10.6 \pm 0.05$ \\
Freeze-drying lyophilisation & $20.23 \pm 0.5$ & 4.21 & $5.86 \pm 0.2$ & $4.9 \pm 0.2$ & $10.8 \pm 0.01$ \\
Ultrafiltration concentration & $35.44 \pm 0.5$ & 1.48 & $3.07 \pm 0.3$ & $2.8 \pm 0.1$ & $8.6 \pm 0.04$ \\
\hline
\end{tabular}




\section{Protein molecular size}

Figure 1 shows the results of SDS-PAGE of whey protein concentrate products and cheese whey. Significant differences among these samples were found. Ultrafiltration offers the fundamental advantage of maintaining the proteins in their native states. This process can used to concentrate whey proteins for biopeptide production [36]. This finding contrasts with the results obtained for other protein concentration methods, such as acetone and ammonium sulphate precipitation, probably because addition of chemical components produces changes in ionic strength and thus perturbations in the proteins. Furthermore, impurities can limit the use of proteins in biopeptide production.

Certain concentration methods significantly increased the true protein content, in contrast to thermal and hydrochloric acid precipitation, which resulted in lower true protein contents. In addition, the molecular structures of whey proteins were not altered by the ultrafiltration or acetone precipitation/lyophilisation methods. The protein concentrate obtained by ultrafiltration, in particular, showed a very similar electrophoretic pattern to that of cheese whey. Major proteins including $\alpha$-La (14.1 $\mathrm{kDa}), \beta-\mathrm{Lg}(20 \mathrm{kDa})$ and serum albumin (BSA; $66.2 \mathrm{kDa})$ were detected in the cheese whey sample and in whey products concentrates obtained by ultrafiltration, freeze-drying and acetone and ammonium sulphate precipitation. A recent report showed that $\beta$-Lg can be isolated from bovine whey using differential precipitation with ammonium sulphate followed by cation-exchange chromatography without altering its structure [37]. The overall yield of purified $\beta-\mathrm{Lg}$ was $14.3 \%$ and the purity was greater than $95 \%$. Therefore, the $\beta$-Lg product can be used for the production of peptides. In contrast, use of the thermal precipitation and hydrochloric acid methods resulted in changes in the electrophoretic pattern. The $\alpha$-La, $\beta$-Lg and BSA bands were no longer detectable (lanes 3, 5). According to Bramaud et al. [38], denaturation of whey proteins can be caused by heating or addition of hydrochloric acid. $\beta-\mathrm{Lg}$ has a denaturation temperature of $74{ }^{\circ} \mathrm{C}$ but precipitates before $\alpha$-La

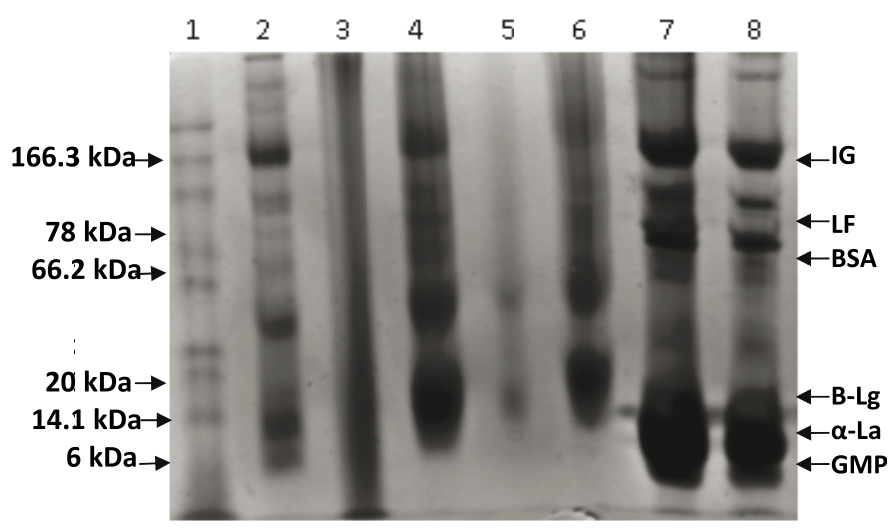

Fig. 1. SDS-PAGE electrophoresis of whey proteins prepared using various methods. 1: Molecular weight marker; 2: Ammonium sulphate precipitation product; 3: Hydrochloric acid precipitation product; 4: Acetone precipitation product; 5: Thermal precipitation product; 6 : Freeze-drying product; 7: Ultrafiltration product; 8: Cheese whey. does. The denaturation of $\alpha$-La is highly reversible compared with that of other proteins; for this reason, it is more heat resistant than $\beta$-Lg [39], but in absence of calcium, $\alpha$-La derived from bovine whey is very unstable $\left(43^{\circ} \mathrm{C}\right)$, because this protein has crystalline form and similar tyrosine and tryptophan contents. Therefore, calcium binding is of the utmost importance for maintaining the structure of this protein. In contrast, the denaturation temperature of BSA is $64{ }^{\circ} \mathrm{C}$, which about the same as that of $\left(62{ }^{\circ} \mathrm{C}\right)$. However, BSA precipitates ahead of $\alpha$-La because $\alpha$-La's denaturation is reversible [40]. Given that the thermal precipitation and hydrochloric acid methods cause denaturation of $\alpha-\mathrm{La}, \beta-\mathrm{Lg}$ and BSA, which are the major precursors of whey peptides, we expect low functionality from the whey products obtained using these precipitation methods.

The minor proteins with MW values of 6-10 kDa observed using SDS-PAGE could be a complex mixture of whey proteins and casein micelles $[41,42]$. These proteins are known as GMP and have an apparent molecular mass of $6.8 \mathrm{kDa}$. Although GMP is not heat sensitive and is a portion of the proteosepeptone fraction [35], our electrophoresis results show that GMP is only present in cheese whey and the whey concentrate products obtained using ultrafiltration and ammonium sulphate precipitation. The presence of GMP can cause the ratio of $\beta$ $\mathrm{Lg}$ and $\alpha$-La to decrease, altering the functionality of the whey products. Jost [43] showed that the GMP content (15-20\%) of WPI manufactured via ultrafiltration of rennet whey has a great impact on protein functionality and peptide production.

In addition, we observed the presence of lactoferrin (LF) and immunoglobulin (Igs) proteins in our electrophoretic study. These proteins were present in cheese whey and the whey products derived via ultrafiltration and ammonium sulphate and acetone precipitation and cheese whey but not in products obtained by addition of hydrochloric acid or thermal precipitation. LF consists of a single polypeptide chain with an MW of 76.5 $\mathrm{kDa}$ that is acid-and heat-stable at $\mathrm{pH} 4.0$ [44]. This protein is part of the innate immune system that defends against microbial infections; its other biological activities include antimicrobial, antioxidant, anti-inflammatory, anticancer and immune regulatory properties [45-48].

The proteins with MWs of $150-1000 \mathrm{kDa}$ observed in our study were identified as Igs. These proteins are potential precursors for immunological peptides and thus their presence in whey products is desirable. Care should be taken to avoid heating: incubation at $65^{\circ} \mathrm{C}$ causes a significant decrease in Ig activity and activity is completely lost upon incubation at 75 ${ }^{\circ} \mathrm{C}$ [49]. Our SDS-PAGE experiment confirms this result: Igs proteins are absent in the whey product obtained by thermal precipitation at $75^{\circ} \mathrm{C}$.

\section{Protein denaturation}

The solubilities of cheese whey and whey concentrate products $\mathrm{pH} 4.6$ and 6.5 are shown in Figure 2. Only the ultrafiltration samples retained their native structure under the conditions applied. The ultrafiltration and cheese whey samples were more soluble at $\mathrm{pH} 6.5$ (94\% solubility) than samples from 


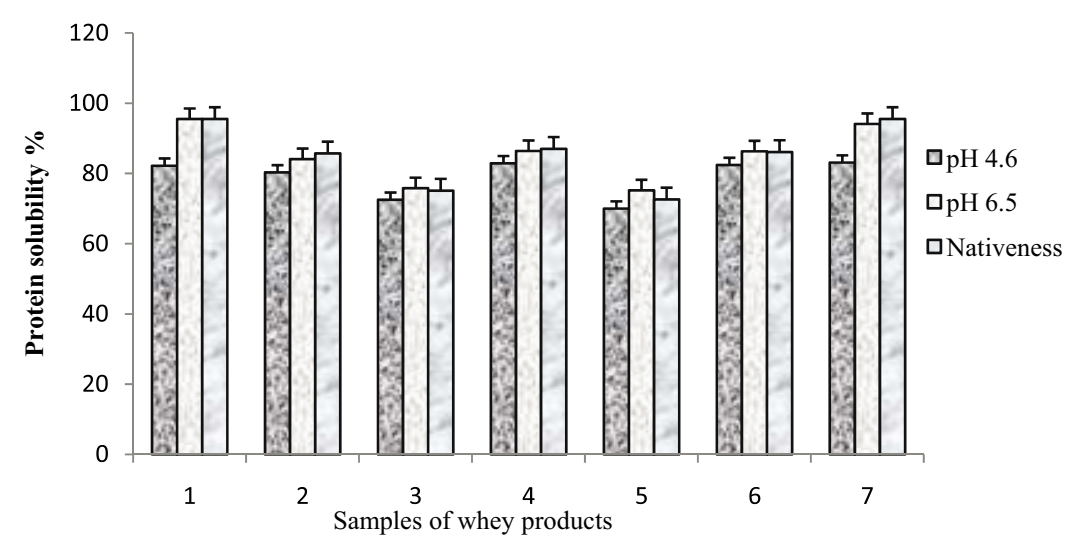

Fig. 2. Solubility (\%) at $\mathrm{pH} 4.5$ and 6.5 and nativeness of whey protein products. 1: Cheese whey; 2: Ammonium sulphate precipitation product; 3: Hydrochloric acid precipitation product; 4: Acetone precipitation product; 5: Thermal precipitation product; 6: Freeze-drying product; 7: Ultrafiltration product.

whey products obtained using other conventional precipitation methods. The products obtained via ammonium sulphate and acetone precipitation had solubilities of $84-86 \%$, while samples obtained via the other protein concentration methods had solubilities in the range of $75-80 \%$. The solubility at $\mathrm{pH}$ 4.5 was significantly lower than that at $\mathrm{pH} 6.5$ for all samples. This $\mathrm{pH}$ test shows that the ultrafiltration products experienced no protein denaturation, as previously shown in an electrophoretic spectral study $[28,50]$. Heat and acidity tend to induce denaturation $[51,52]$ and consequently decrease the solubility of the whey proteins in the WPC. The lower solubility of the whey products from precipitates produced by heating was probably due to thermocalcic precipitation [53]. The free sulphydryl content of the whey protein concentrate is significantly correlated to the protein solubility. It has been suggested that decreased solubility is due to a decrease in soluble $\beta-\mathrm{Lg}$, which results in a decreased concentration of free sulphhydryl groups, which are required to form the gel matrix at this $\mathrm{pH}$. It has long been known that the calcium concentration has a large effect on the heat stability of both $\beta-\mathrm{Lg}$ and $\alpha$-La. Thus, the effect of heat denaturation on the calcium content is probably responsible for the effects of heat treatment on solubility. Extreme acidity or high salt levels can also cause decreases in protein solubility because $\beta$-Lg forms white particulate gels at pH 4-6 and transparent fine-stranded gels at neighbouring $\mathrm{pHs}$, thus adversely affecting solubility. The water holding capacity (WHC) of whey proteins is also negatively affected by acid $\mathrm{pH}$ and salts, which lead to aggregation and viscosity. WHC decreases slightly at $\mathrm{pH} 4.0$ and 5.0 , while $100 \mathrm{mM}$ salt held only $6 \mathrm{~g}$ of water per gram protein [54]. Finally, when $\beta$ - $\mathrm{Lg}$ is exposed to higher temperatures, $\beta$ - $\mathrm{Lg}$ dimers dissociate. This property should be taken into consideration for hydrolysis of whey products because it influence protein solubility and hence enzyme penetration and hydrolysis.

\section{Antimicrobial capacities of whey protein concentrates}

Antimicrobial experiments showed that only two whey products had a consistent effect on Gram-negative bacteria. Whole whey and the ultrafiltration concentrate product had antimicrobial effects on Klebsiella pneumonae, Pseudomona aeruginosa and Escherichia coli. Figure 3 shows the inhibition halo data obtained using the ultrafiltration concentrate product in disk tests with Gram-positive and Gram-negative bacteria. Nalidixic acid is a positive control. After $3 \mathrm{~h}$ and $24 \mathrm{~h}$ of incubation with the whole whey, there were inhibition zones of $>25 \%$ and $40 \%$, respectively, for the Gram-negative strains. Nalidixic acid produced a $90 \%$ inhibition zone. The ultrafiltration products had a smaller effect on the Salmonella sp strains than the whole whey.

The products obtained using freeze-drying also had a bactericidal effect on Escherichia coli, but the activity of these samples was $30 \%$. The other whey products had no apparent effect on the bacterial cells.

The antimicrobial activity of whey products can be attributed to the iron-binding property of $\alpha-\mathrm{La}, \beta-\mathrm{Lg}$, LF, lactoperoxidase (LP), BSA and lysozyme. These proteins decrease the iron available to the microorganisms and also act by direct binding to microbial membranes. However, their effects are not limited to bacteria with iron requirements (e.g., coliforms), particularly in the case of LF. LF can damage the outer membranes of Gram-negative bacteria via binding to Lipid A lipopolysaccharides (LPS) [55] and enhance bacterial susceptibility to hydrophobic antimicrobials such as lysozyme. However, other studies have showed that addition of cations, such as $\mathrm{Ca}^{2+}$ inhibits LF binding to LPS, as does the addition of polymyxin B [56]. Further studies have shown that LF is bactericidal only when in its iron-free state and that iron-saturated LF has a reduced antimicrobial activity [57].

This data could explain the low antimicrobial activity of the whey concentrate products. The presence of $\mathrm{Ca}^{2+}$, the saturation of $\mathrm{NH}_{4}{ }^{+}$ions and protein denaturation may all affect the antimicrobial capacity of these products.

Peptides generated from existing whey products via proteolytic reactions may have antimicrobial effects. The anti-E. coli activity of enzymatic hydrolysates generated by digestion with porcine pepsin is greater than that of whole LF [58]. Pep- 


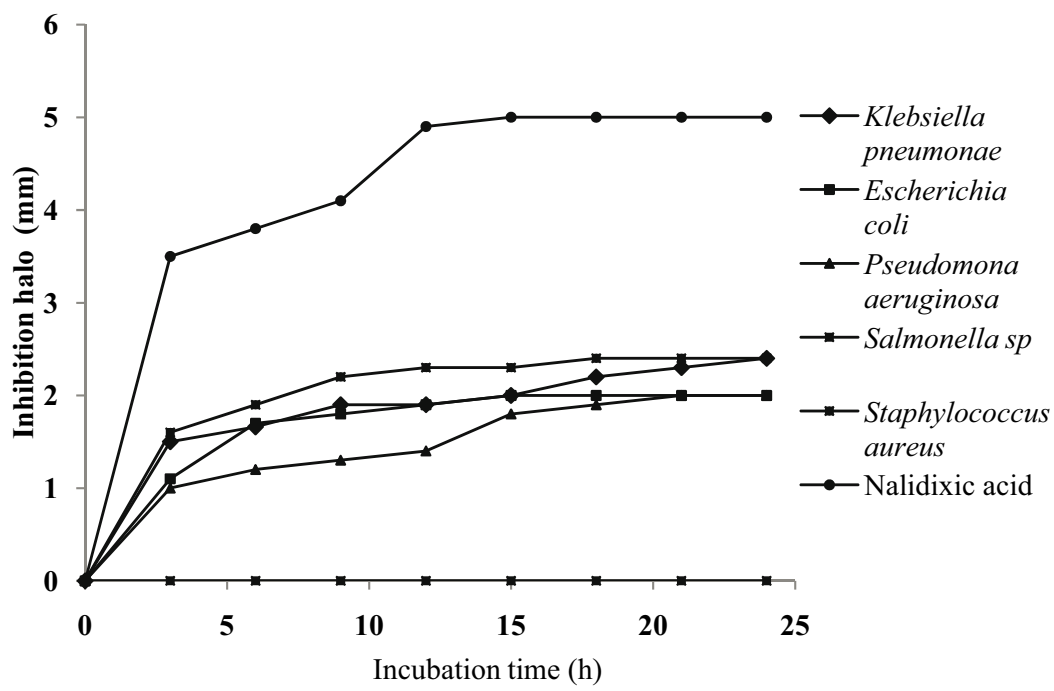

Fig. 3. Antimicrobial activity of the ultrafiltration concentrate product. The sizes of inhibition halos were determined in disk tests using the Gram-positive bacterium Staphylococcus aureus and the Gram-negative bacteria Klebsiella pneumonae, Pseudomona aeruginosa, Salmonella sp and Escherichia coli. Nalidixic acid is also shown as a positive control for activity against Escherichia coli.

tide fragments of 25 amino acids that are exact homologous to an amino-terminal segment of LF have been shown to have antibacterial activity $[48,59]$.

\section{Antioxidant capacities of whey protein concentrates}

Table 2 shows the antioxidant activities of whey protein products and whey samples obtained in a 10-min assay. Data are expressed as antioxidant activity equivalent to ascorbic acid (AAEAA). The values ranged from 0.5 to $12 \mu \mathrm{M} / 100 \mathrm{~g}$ of whey protein product.

The whey protein concentrates obtained by ultrafiltration and freeze-drying had significant ABTS•+ radical scavenging activities. The lowest AAEAA values were those of the whey product concentrates obtained via precipitation methods, which had values between 0.4-2.0 $\mu \mathrm{M}$. Differences in whey protein compositions and the severity of the isolation treatments had a significant effect on the antioxidant activity of the whey protein products. These results are explained in Bounous and Gold [60], in which the authors showed that low temperature-processed whey protein contains high levels of specific dipeptides (e.g., glutamylcysteine) than promote the synthesis of glutathione, an important antioxidant involved in cellular protection and repair processes. Tseng et al. [61] showed that a WPC product promotes gluthanione production, which in turn enhances antioxidant activity in a pheochromocytoma (PC12) cell line after acute ethanol exposure. Tong et al. [62] found that BSA has potential antioxidant activity. Bayram et al. [63] measured the antioxidant activity of whole whey proteins and whey hydrolysates. A comparative study showed that proteolysis of whey promotes the production of peptides with high AAEAA values, most of which seem to be derivatives of $\beta$ - $\mathrm{Lg}$. The antioxidant capacity of whey has also been attributed to the presence of hydrophobic amino acids, such as tyrosine, methionine, histidine, lysine and tryptophan [64]. In addition, Baltzell et al. [65] found that free amino acids (FFA) are also able to capture free ABTS $\bullet+$ radicals. FAA compounds as ornithine, carnitine and taurine are sources of non-protein nitrogen in whey products and play important roles in facilitating the transport of fatty acids, particularly long-chain fatty acids, into the mitochondrial matrix for oxidation.

\section{Experimental Methods}

\section{Materials}

Bovine cheese whey $(10 \mathrm{~L})$ was used to obtain whey concentrate products. Samples of $500 \mathrm{~mL}(511.5 \mathrm{~g})$ of whey were stored at $5{ }^{\circ} \mathrm{C}$ before use. Standard Methods [18] and Official Methods of Analysis [19] were used for the determination of the following parameters. The protein composition analysis

Table 2. Antioxidant capacity ( $\mu \mathrm{M}$ AAEAA/100 g powder) of whey protein products.

\begin{tabular}{ccccccc}
\hline Whey sample & $\begin{array}{c}\text { Salt } \\
\text { treatment }\end{array}$ & $\begin{array}{c}\text { Acetone } \\
\text { precipitation }\end{array}$ & $\begin{array}{c}\text { Hydrochloric } \\
\text { acid precipitation }\end{array}$ & $\begin{array}{c}\text { Thermal } \\
\text { precipitation }\end{array}$ & $\begin{array}{c}\text { Freeze-drying } \\
\text { lyophilisation }\end{array}$ & Ultrafiltration \\
\hline $9.44 \pm 0.1$ & $1.92 \pm 0.1$ & $2.05 \pm 0.1$ & $0.48 \pm 0.1$ & $0.41 \pm 0.1$ & $12.04 \pm 0.2$ & $9.55 \pm 0.1$ \\
\hline
\end{tabular}


was determined as the total nitrogen $\mathrm{TN}$ using the method of Kjeldahl and a conversion factor of 6.38. A colorimetric method was used to determine the total sugar content; the ash content was measured by heating at $550{ }^{\circ} \mathrm{C}$ overnight in a muffle furnace, while the $\mathrm{pH}$ of the whey was measured using a potentiometer $\left(\right.$ Checker $\left.^{\circledR}\right)$. Fat content was determined according to a gravimetric procedure; chloride content was measured using a Sigma Diagnostics kit (Sigma-Aldrich Chemical Co) and $\mathrm{Ca}^{2+}$ content was determined by atomic absorption spectrometry (PerkinElmer, model 2380). Each measurement, including those described below, was performed in triplicate.

\section{Whey protein concentration methods}

Various concentration methods (individual addition of ammonium sulphate, acetone and hydrochloric acid, thermal precipitation, ultrafiltration and lyophilisation) were used for whey protein separation. Cheese whey samples of $500 \mathrm{~mL}(n=3)$ were used in all trials. Table 3 summarises the traditional methods and operation conditions for whey protein concentration.

The proteins obtained via each precipitation method were recollected by centrifugation at $13,000 \times \mathrm{g}$ for $15 \mathrm{~min}$, subjected to dialysis using a membrane (Thermo Scientific ${ }^{\circledR}$, pore size $=10,000$ Daltons) and then filtered through nitrocellulose filter paper (Millipore ${ }^{\mathbb{R}}$ ) with a pore size of $0.45 \mu \mathrm{m}$. Dialysis was performed until the samples reached conductivities of $<1$ $\mu \mathrm{S} \mathrm{cm}^{-1}$. The concentrated protein solutions were then obtained in paste form. The concentrated products were dried at $75{ }^{\circ} \mathrm{C}$ in an oven (Riossa ${ }^{\circledR}$ ) for $24 \mathrm{~h}$. The paste was ground using a hammer mill, sifted through a $150-\mu \mathrm{m}$ aperture screen and stored in a refrigerator at $5{ }^{\circ} \mathrm{C}$ until use.

For the ultrafiltration method, proteins were concentrated using cross-flow zirconium-titanium ceramic membranes (50 $\mathrm{kDa}$ cut-off and $0.020 \mathrm{~m}^{2}$ effective membrane areas). The inlet and outlet pressures were adjusted and controlled to $5.0 \mathrm{bar}$, and 0.8 bar respectively; the temperature was maintained at $35{ }^{\circ} \mathrm{C}$. After approximately $24 \mathrm{hr}$, the UF was stopped and the whey concentrated to a volume concentration ratio (VCR) of 15. Diafiltration was performed by addition of five volumes of deionised water to the retentate to maintain a constant volume.

\section{Characteristics of whey protein concentrates (WPC)}

\section{Nutritional properties}

The WPC products were characterised by the same analytical methods used for the whey samples. The protein composition analysis was determined using the total nitrogen TN (determined using the Kjeldahl method), non-protein nitrogen (NPN; defined as the Kjeldahl nitrogen soluble in $12 \%$ trichloroacetic acid) and non-protein nitrogen components (NPNC; equal to NPN x 3.60). The true protein content was determined as (TNNPN) x 6.45 [20]. Molecular weight (MW) profiles and antioxidant and antimicrobial capacities of proteins were determined as described below.

\section{Protein molecular size}

Sodium dodecyl sulphate-polyacrylamide gel electrophoresis (SDS-PAGE) using a $4 \%$ stacking gel and a $15 \%$ separating gel was performed to determine the molecular sizes of various whey proteins. The continuous buffer contained $0.125 \mathrm{M}$ Tris$\mathrm{HCl}(\mathrm{pH} 6.8)$ and $0.1 \%$ SDS for the stacking gel and 0.375 $\mathrm{M}$ Tris- $\mathrm{HCl}(\mathrm{pH} 8.8$ ) and $0.1 \%$ SDS for the separating gel. The running buffer contained $0.124 \mathrm{M}$ Tris, $0.959 \mathrm{M}$ glycine and $0.1 \%$ SDS (pH 8.3). All samples were added to dissociating buffer $(0.5 \mathrm{M}$ Tris- $\mathrm{HCl}(\mathrm{pH} 6.8)$, glycerol and $1 \%(\mathrm{w} / \mathrm{v})$ bromophenol blue). Each solution was heated at $100{ }^{\circ} \mathrm{C}$ for 4 min, cooled and centrifuged at 5,000 rpm (Labnet Spectrafuge $16 \mathrm{M}$, Labnet International, Edison, NJ) for $5 \mathrm{~min}$ to remove insoluble material. An aliquot of each sample containing 0.01

Table 3. Traditional methods used for whey protein concentration.

\begin{tabular}{|c|c|c|c|}
\hline $\begin{array}{l}\text { Whey protein } \\
\text { concentration } \\
\text { method }\end{array}$ & Procedures & $\begin{array}{c}\text { Temperature } \\
\left({ }^{\circ} \mathrm{C}\right)\end{array}$ & $\begin{array}{c}\text { Time } \\
\text { (h) }\end{array}$ \\
\hline Salt treatment & $\begin{array}{l}\text { Addition of ammonium sulphate ( } 760 \\
\mathrm{~g} / \mathrm{L} \text { ) }\end{array}$ & 20 & 2.0 \\
\hline $\begin{array}{l}\text { Acetone } \\
\text { precipitation }\end{array}$ & Addition of acetone $(250 \mathrm{~mL} / \mathrm{L})$ & -20 & 2.0 \\
\hline $\begin{array}{l}\text { Hydrochloric acid } \\
\text { precipitation }\end{array}$ & $\begin{array}{l}\text { Addition of hydrochloric acid ( } 4 \mathrm{M}) \text {, } \\
\text { adjustment of } \mathrm{pH} \text { to } 4\end{array}$ & 60 & 2.0 \\
\hline $\begin{array}{l}\text { Thermal } \\
\text { Precipitation }\end{array}$ & Heating & 75 & 1.0 \\
\hline $\begin{array}{l}\text { Freeze-drying } \\
\text { lyophilisation }\end{array}$ & Dehydration process & -20 & 24.0 \\
\hline $\begin{array}{l}\text { Ultrafiltration } \\
\text { concentration }\end{array}$ & $\begin{array}{l}\text { Laboratory-scale ceramic membrane } \\
\text { (feed rate } 0.28 \mathrm{~L} / \mathrm{h} \text {; cross-flow velocity } \\
1.5 \mathrm{~m} / \mathrm{s} \text {; transmembrane pressure } 5 \text { bar) }\end{array}$ & 32 & 6.5 \\
\hline
\end{tabular}


mg protein and $4 \mu \mathrm{L}$ MW standards were loaded into each well. The samples were electrophoresed at an initial voltage of 80 $\mathrm{V}$ for $20 \mathrm{~min}$, after which the voltage was increased to $100 \mathrm{~V}$. Gel slabs were fixed and stained simultaneously using Bio-Rad Coomassie Blue R-250 stain solution (40\% methanol, $10 \%$ acetic acid, 0.1\% Coomassie Blue R-250) for $30 \mathrm{~min}$ and were then de-stained in Bio-Rad Coomassie Blue R-250 de-staining solution for $5 \mathrm{~h}$ with 2-3 changes of the de-staining solution. The MW of proteins was determined using full-range rainbow MW markers of approximately 10-250 kDa and low-range MW markers of approximately $2.5-45 \mathrm{kDa}$.

\section{Determination of denaturation status}

The denaturation statuses of the whey protein products were tested by examining protein solubility. The solubilities at $\mathrm{pH}$ 4.5 and 6.5 were determined in triplicate using samples from whey products in powder form and following the method of Morr et al. [21]. Solubility was calculated as the total protein concentration in the supernatant after centrifugation at $\mathrm{pH} 4.6$ as a percentage of the initial concentration at $\mathrm{pH}$ 6.5. Whey product samples $(5 \mathrm{mg})$ were dissolved in $0.4 \mathrm{~mL}$ of $0.1 \mathrm{M}$ $\mathrm{NaCl}$. The $\mathrm{pH}$ was adjusted to 4.6 or 6.5 in individual solutions using $0.1 \mathrm{~N} \mathrm{HCl}$ or $\mathrm{NaOH}$. The dispersions were stirred for 1 $\mathrm{h}$; during this period, the $\mathrm{pH}$ was adjusted. The dispersion was transferred into a $25 \mathrm{~mL}$ volumetric flask and diluted to the mark with additional $0.1 \mathrm{M} \mathrm{NaCl}$ solution. The solution was centrifuged for $30 \mathrm{~min}$ at 20,000 $\mathrm{xg}$, and the resulting supernatant fraction was filtered through Whatman No. 1 filter paper. The protein contents of the filtrate and the original dispersion were determined using the Lowry method. The protein solubility was calculated as a percentage.

\section{Antimicrobial capabilities of whey protein concentrates: agar disk diffusion assay}

The antimicrobial capacities of the whey protein products were evaluated in disk susceptibility tests using the following bacterial strains: gram-positive: Staphylococcus aureus; gram-negative: Klebsiella pneumonae, Pseudomona aeruginosa, Salmonella sp. and Escherichia coli [22].

Strains were stored as $50 \%$ glycerol stocks at $-20{ }^{\circ} \mathrm{C}$. Nutritive agar stock dishes were inoculated with $200 \mu \mathrm{L}$ of the inocula with absorbances of 0.2 [23]. The samples (200 $\mu \mathrm{g}$ of protein) were formed in pre-sterilised 6-mm disks. After eliminating any excess product, the disks were deposited symmetrically using sterile forceps. The dishes were incubated for $24 \mathrm{~h}$ at $37{ }^{\circ} \mathrm{C}$. The size of the zone of growth inhibition was used as a measure of antimicrobial activity. Nalidixic acid and nizoral were used as positive controls.

\section{Antioxidant activity equivalent to ascorbic acid (AAEAA) assay}

The AAEAA assay described by Miller et al. [24] was used to evaluate the relative antioxidant capacity of the whey protein ex- tract with regard to the scavenging of ABTS radicals compared to the antioxidant potency of ascorbic acid (AA). According to the methodology developed by Re et al. [25], ABTS•+ radicals were obtained by the reaction of ABTS (7 mM, AMRESCO $\left.{ }^{\circledR}\right)$ with potassium persulphate $(2.45 \mathrm{mM})$ which was performed at room temperature in the dark for $16 \mathrm{~h}$. The ABTS•+ stock solution was diluted with phosphate buffered saline (PBS) $\mathrm{pH}$ 7.4 to obtain an absorbance of $0.70( \pm 0.1)$ at $734 \mathrm{~nm}$ at $30{ }^{\circ} \mathrm{C}$ [26]. After the addition of $2 \mathrm{~mL}$ of the diluted ABTS $\cdot+$ solution to $20 \mathrm{~mL}$ of whey product sample or ascorbic acid standards (Sigma Aldrich) with a final concentration of ascorbic acid ranging from 0 to $8 \mathrm{mg} / \mathrm{mL}$ in PBS, absorbance was recorded every min for $10 \mathrm{~min}$ at $30^{\circ} \mathrm{C}$. Appropriate solvent blanks were run in each assay. The activity of each sample was measured in duplicate. The percentage inhibition of absorbance at 734 $\mathrm{nm}$ was calculated as a function of the antioxidant concentration. The results were expressed as the antioxidant activity equivalent to ascorbic acid (AAEAA). A spectrophotometer (PerkinElmer Lambda 35) was used for all trials.

\section{Conclusions}

Whey bioactive peptides are produced from hydrolysates of individual proteins or set protein in a purified or enriched form. However the severity of some methods for isolating and concentrating of whey proteins can affect the products performance and their biological capacity, affecting also production and biofunctionality of peptides.

Comparison of concentrating methods of precipitation, ultrafiltration and freeze drying on samples from bovine cheese whey showed that the most high true protein content was obtained by ultrafiltration and ammonium sulphate precipitation. Effective concentration of these products was approximately $40-53 \%(\mathrm{w} / \mathrm{w})$ protein.

Electrophoresis study indicated significant differences among the concentrate products. Methods of ultrafiltration, freeze-drying and precipitation by means acetone and ammonium sulphate did not alter the protein structure of $\alpha-\mathrm{La}, \beta-\mathrm{Lg}$ and BSA. Ultrafiltration method offered the fundamental advantage of maintaining the LF and Igs proteins in their native state. In contrast, use of the thermal precipitation and hydrochloric acid methods resulted in changes in the electrophoretic pattern; the protein bands were no longer detectable. In addition the solubility analysis of proteins confirmed the retaining of native structure of ultrafiltration products at $\mathrm{pH}$ of 4.6 and 6.5 , while the other concentrate products were less soluble under these conditions. This property should be taken into consideration for hydrolysis of whey products because it can affect enzyme penetration and hydrolysis process.

Respect to biological function, important ABTS•+ radical scavenging activity was found in products from free-drying, ammonium sulphate precipitation and ultrafiltration. Antioxidant activity was attributed at $\alpha-\mathrm{La}, \beta-\mathrm{Lg}$ and BSA proteins and hydrophobic amino acids contained in these products. 
In contrast, all products showed low antimicrobial activity or null, due to probably inhibition of LF and $\beta$-Lg. The presence of $\mathrm{Ca}^{2+}$, the saturation of $\mathrm{NH}^{4+}$ ions and protein denaturation may all affect the antimicrobial capacity of these products.

\section{Acknowledgements}

We gratefully acknowledge CONACyT and the government of the State of Hidalgo (Mexico) for financial support (project number HGO-2008-01-98068).

\section{References}

1. Sinha, P. R.; Rahda, C.; Prakash, J.; Kaul, P. Food Chem. 2007, 101, 1484-1491.

2. Muro-Urista, C.; Álvarez-Fernández, R.; Riera-Rodríguez, F.; Arana-Cuenca, A.; Téllez-Jurado, A. Food Sci. Technol. Int. 2011, 17, 293-317.

3. Gauthier, S. F.; Pouliot, Y.; Saint-Sauveur, D. Int. Dairy J. 2006, 16, 1315-1323.

4. Mensink, R. P. Int. Dairy J. 2006, 16, 1001-1004.

5. Pfeuffer, M.; Schrezenmeir, J. Obes. Rev. 2006, 8, 109-118.

6. Scholz-Ahrens, K. E.; Schrezenmeir, J. Int. Dairy J. 2006, 16, 1399-1407.

7. Korhonen, H. J. Funct. Foods 2009, 1, 177-187.

8. Clare, D. A.; Swaisgood, H. E. J. Dairy Sci. 2000, 83, $1187-$ 1195.

9. Gobbetti, M.; Morea, M.; Baruzzi, F.; Corbo, M. R.; Matarante, A.; Considine, T.; Cagno, R.; Guinee, T.; Fox, P. F. Int. Dairy J. 2002, 12, 511-523.

10. Marsall, K. Altern. Med. Rev. 2004, 9, 136-156.

11. Cheang, B.; Zydney, A. L. Biotechnol. Bioeng. 2003, 83, 201209.

12. Etzel, M. R. J. Nutr. 2004, 134, 996-1002S.

13. Beolchini, F.; Veglio, F.; Barba, D. Desalination 2004, 161, 251258.

14. Casal, E.; Montilla, A.; Moreno, F. J.; Olano, A.; Corzo, N. $J$. Dairy Sci. 2006, 89, 1384-1389.

15. Korhonen, H. Int. J. Dairy Technol. 2002, 55, 79-88.

16. Foegeding, E.; Luck, P., in: Encyclopedia of Food Sciences and Nutrition. Caballero, B., Trugo, L., Finglas, P., (Ed.), Academic Press, New York, 2002; pp. 1957-1960.

17. Chollangi, A.; Hossain, Md. M. Chem. Eng. Process. 2007, 46, 398-404.

18. Wehr, H. M.; Frank, J. F., in: Standard Methods for the Examination of Dairy Products. American Public Health Association 17th (Ed.), 2004; pp. 363-519.

19. Horwitz, W.; Latimer, G. W., in: Official methods of analysis of $A O A C$, 18th Ed., Jr, (Ed.), International, Gaithersburg MD: AOAC International. 2007; pp. 27.

20. Karman, A. H.; Van Boekel, M. A. J. S. Milk Dairy J. 1986, 40, 315-336.

21. Morr, C.; German, B.; Kinsella, J.; Regenstein, J.; Van Buren, J.; Kilara, A.; Lewis, B.; Mangino, M. J. Food Sci. 1985, 50, 17151718.

22. Figueroa, L.; Díaz, F.; Ceballos, G.; López, M. J. Mex Chem Soc. 2008, 52, 130-135.

23. Bauer, A. W.; Kirby, W. M.; Sherris, J. C.; Turck, M. Am. J. Clin. Pathol. 1966, 45, 493-496.

24. Miller, N. J.; Rice-Evans, C. A. Free Radic. Res. 1997, 26, $195-$ 199.
25. RE, R.; Pellegrini, N.; Proteggente, A.; Pannala, A.; Yang, M.; Rice-Evans, C. Free Radic. Biol. Med. 1999, 26, 12311237.

26. Camacho, A.; Gayosso, J. A.; Torres, J. M.; Muñoz, J. L.; Alarcón, E.; López, R.; Barrón, B. L., J. Mex Chem Soc. 2008, 52, 103107.

27. Pereira, C. D.; Díaz, O.; Cobos, A. Int. Dairy J. 2002, 12, 773783.

28. Díaz, O.; Pereirab, D.; Cobosa, A. Food Hydrocolloids 2004, 18 : 601-610.

29. Panesar, P.; Kennedy, J.; Gandhi, D.; Bunko, K. Food Chem. 2007, 105, 1-14.

30. Monsalve, J.; González, D. Rev. Cientif. (FCV-LUZ) XV 2005, 6, 543-550.

31. Valdés-Martínez, S., in: Química de Alimentos, Badui, S., (Ed.), Pearson Educación, Ciudad de México, México, 2006; pp. 29109.

32. Nakajima, K.; Tamura, N.; Kobayashi-Hattori, K.; Yoshida, T.; Hara-Kudo, Y.; Ikedo, M.; Suguita-Kosishi, Y.; Hattori, M. Biosci. Biotechnol. Biochem. 2005, 69, 2294-2301.

33. Guéguen, L; Pointillart, A. J. Am. Coll. Nutr. 2000, 19, 119S$136 \mathrm{~S}$.

34. Warner, E. A.; Kanekanian, A. D.; Andrews, A. T. Int. J. Dairy Technol. 2001, 54, 151-153.

35. Modler, H. W., in: Food Proteins Nakai, S; Modler, HW., (Ed.), New York, 2000, pp. 1-88.

36. Atra, R.; Vatai, G.; Molnar, E. B.; Balint, A. J. Food Eng. 2005, 67, 325-332.

37. Lozano, J. M.; Giraldo, G. I.; Romero, C. M. Int. Dairy J. 2008, $18,55-63$.

38. Bramaud, C.; Aimar, P.; Daufin, G. Dairy Sci. Technol. 1997, 77, 411-423.

39. Walstra, P.; Wouters, J. T. M.; Geurts, T. J., in: Dairy Science and Technology, CRC Press/Taylor and Francis Group, Boca Raton, 2006; pp. 297-339; 497-550.

40. Brown, R. J., in: Fundamentais of dairy chemistry. Van Nostrand Reinhold Company Inc., New York, 1988; pp. 583-607.

41. Vasbinder, A. J.; de Kruif, C. J. Int. Dairy J. 2003, 13, 669-677.

42. Donato, L.; Guyomarc'h, F. Dairy Sci. Technol. 2009, 89, 3-29.

43. Jost, R. Trends Food Sci. Technol. 1993, 4, 283-288.

44. Tomita, M.; Hiroyuki, W.; Kouichirou, S.; Koji, Y.; Tomoko, Y.; Keiji, I. Biochimie 2009, 91, 52-57.

45. Lönnerdal, B. Am. J. Clin. Nutr. 2003, 77, 1537S-1543S.

46. Wakabayashi, W.; Yamauchi, K.; Takase, M. Int. Dairy J. 2006, 16, 1241-1251.

47. Pan, Y.; Lee, A.; Wan, J.; Coventry, M. J.; Michalski, W. P.; Shiell, B.; Roginski, H. Int. Dairy J. 2006, 16, 1252-1261.

48. Zimecki, M.; Kruzel, M. L. J. Exp. Ther. Oncol. 2007, 6, 89106.

49. Agamy, E. I. Food Chemistry 2000, 68, 227-232.

50. Harper, W. J.; Man Lee, K. Int. Dairy Fed. 1998, (Special Issue) 9804: 140-153.

51. DeWit, J. N.; Klarenbeek, G. J. Dairy Sci. 1984, 67, 2701-2710.

52. Li-Chan, E. J. Food Sci. 1983, 48, 47-56.

53. Mangino, M. E; Huffman, L. M; Regester, G. O. J. Food Sci.1988, 53, 1684-1686.

54. Hudson, H. M.; Daubert, C. R. J. Texture Stud. 2002, 33, $297-$ 314.

55. Madureira, A. R.; Pereira, C. I.; Gomes, A. M. P.; Pintado, M. E.; Malcata, F. X. Food Res. Int. 2007, 40, 1197-1211.

56. Appelmelk, B. J.; An, Y. Q.; Geerts, M.; Thijs, B. G.; de Boer, H. A.; MacLaren, D. M.; de Graaff, J.; Nuijens, J. H. Infect. Immun. 1994, 62, 2628-2632.

57. Yamauchi, K.; Tomita, M.; Giehl, T. J.; Ellison, R. T. Infect. Immun. 1993, 61, 719-728. 
58. Lupetti, A.; Paulusma-Annema, A.; Welling, M. M.; DogteromBallering, H.; Brouwer, C. P.; Senesi, S.; Van Dissel, J. T.; Nibbering, P. H. Antimicrob. Agents Chemother. 2003, 47, 262-267.

59. Misonou, H.; Morishima-Kawashima, M.; Ihara, Y. Biochem. 2000, 39, 6951-6959.

60. Bounous, G.; Gold, P. Clin. Invest. Med. 1991, 14, 296-309.

61. Tseng, Y. M.; Lin, S. K.; Hsiao, J. K.; Chen, I. J.; Lee, J. H.; Wu, S. H. Food Chem. Toxicol. 2006, 44, 574-578.
62. Tong, L. M.; Sasaki, S.; McClements, D. J.; Decker, E. A. J. Agric. Food Chem. 2000, 48, 1473-1478.

63. Bayram, T.; Pekmez, M.; Arda, N.; Yalcin, A. Talanta 2008, 75, 705-709.

64. Erdmann, K.; Cheung, B.; Schroder, H. J. Nutr. Biochem. 2008, $19,643-54$.

65. Baltzell, J. K.; Bazer, F. W.; Miguel, S. G.; Borum, P. R. J. Nutr. 1987, 117, 754-757. 